\title{
The Cultural Meaning of Traditional Expressions in Daily Speech of Using Community at Banyuwangi
}

\author{
Imam Suyitno \\ State University of Malang. \\ Email: imam.suyitno.fs.@um.ac.id
}

\begin{abstract}
This article aims to describe a variety of traditional expressions used by Using community at Banyuwangi in speaking. The variety of expressions is studied from the form, usage, and cultural meaning in communication. The data of traditional expression speech presented in the description sources from conversation of Using community in various speech situations. The result of the study shows that there are 6 categories of traditional expressions used in the Using speech community. The variety of the expressions used by the speaker to express a message, thoughts, feelings, or opinions to the speaking participan. Various things that can be conveyed through expression are praise, anger, aggravation, suggestions or advice, and pleasure. Using community utilizes the expressions to criticize, comment, ridicule, reassuring, stated, praising, reprimanding or blaming, complaining, remind, advise, and ask or beg. All of them are reflecting Using community culture in daily speech.
\end{abstract}

Keywords: cultural meaning, traditional expressions, daily speech, Using community

\section{INTRODUCTION}

Using community speech is a group of speakers who come from the original tribe of Banyuwangi. Individuals who are members of the Using community are called wong Using. Some of Wong Using live in a social unity of Using ethnic and others coexist with other ethnic. Another dominant ethnic in the region of Banyuwangi is the Javanese called wongKulonan, the Madurese called wongMeduro, the Balinese tribe known as wong Bali. In carrying out cultural practices among the community, wong Using generally applies Using language, but if communicating with other ethnic groups, they use Javanese or Indonesian language.

Banyuwangi Regency with an area of $5,782.50 \mathrm{~km} 2$ inhabited by population as much as 1.668 .438 people, consisting of 838,856 men and 829,582 souls of the female, the population is spread in 24 sub-districts namely Pesanggaran, Bangurejo, Purwoharjo, Tegaldelimo, Muncar,
Cluring, Gambiran, Srono, Genteng, Glenmore, Kalibaru, Singojuruh, Rogojampi, Kabat, Glagah, Banyuwangi, Giri, Wongsorjo, Songgon, Sempu, Kalipuro, Siliragung, Tegalsari, Licin.The largest population is in Muncar sub-district of 133.009 Soul (7.97\%), while Licin District has the smallest population of 28,238 inhabitants (1.69\%). The indigenous population consists of wong Using, wong Kulonan, wong Meduro, wong Bali, and immigrants from other regions, while nonindigenous residents are mostly Chinese, and some are Arabs, Dutch, English, and Pakistani. Wong Using population is estimated to reach not more than 1 thousand inhabitants (Pemerintah Kabupaten Banyuwangi, 2015).

Most of Usingpeople's livelihoods are farm laborers. The largest agricultural product is rice. Other agricultural products are corn, peanuts, soybeans, and sweet potatoes. In addition to farm laborers, the livelihoods of Using societies are 
industrial laborers, such as basic chemicals, metals, food industries, and buildings. The number of Using people who become traders, civil servants, and fishermen is relatively small (Marwoto, et al., 1999). Socially, this fact indicates that the life of the people of Using is categorized as simple life (Ali, 1993).

Using community, in general, is religious community. Nonetheless, the Using people still preserve the cultural traditions of their society. Traditional celebrations for the origin of the village, to the salvation of their ancestors, and safety requirements for rice are still often found in their lives. They also still use the offerings put in places that are considered sacred, such as in the water source used for bathing and washing (Kementrian Kebudayaan dan Pariwisata, 2004). Using community also has a tradition of respecting myths in life, which includes the tradition of marriage of first child, traditional of marriage youngest child, traditional ceremonies of women pregnant, traditional ceremonies of anak kluwung 'rainbow child', traditional ceremonies of anak mondal-mandil 'only child' (Aksoro, 2004).

Understanding of cultural norms by community members has variousfunctions. According to Pusat Informasi Tentang Kesenian dan Kebudayaan(2016), cultural understanding serves as a means to study the culturalbehavior of the older generation's inheritance in order to select cultures thatare worthy of defense and culture that should be renewed or abandoned. Because the nature of culture is dynamic, we can know which culture will beabandoned, defended, or enhanced. The development of a culture is stronglyinfluenced by the power of culture itself and the intensity of cultural interactionwith other cultures. Weak cultures or minorities are generally supported bystronger and more dominant cultures. As a result, the weak and minorityculture will change as it gets the influence of the great culture that governs it.

Conversely, cultures with limited interaction with other cultures tend to slowlyevolve and changeThe culture of a society will change and develop rapidly becauseof theinfluence of external factors. The large number of new entrants entering thearea is the main factor causing the acculturation of the culture of the society.Heinemann, Atallah, and Rosenbaum (2016) explain that acculturation or theprocess of adaptation that occurs when an immigrant raises in one culturearrives in another country with a different culture by which sociocultural,influences can be examined. One of these changes is the change oflanguage owned by the community (Pusat Informasi Tentang Kesenian danKebudayaan, 2016) and changes in the culture of language use in interactionbetween individuals within the community.

In carrying out daily cultural activities, Using communities internally communicate use Using language. In speech communication, Usingpeople often use the expression that had been conceived jointly termed traditional expression. Cervantes, as quoted by Danandjaja (1982:1), explains that the traditional expression is a short sentence extracted from long experience. The expressions is not only as a policy but also describes a person's intelligence. Those expressions are proving their moral attitude is aspired by members of the community (Sastrowardojo, 1985: 49). The moral attitude expected of members of the public in dealing with various life situations, including situations of life in relation to God, human beings, and nature.

Every civilized society always has language and use language to communicate. In this case, the language becomes a prerequisite to survive, and development of a society and culture because language is one of the bonds reinforcing social and cultural development (Suyitno, 2017). Therefore, culture and language can not be separated or divorced. Both have a reciprocal relationship (Nababan, 1984:72).This facts show that between culture and language society can not beseparated or divorced. In fact, it can be said that language is the identity of itsspeaker community (Auer, 2007).

Under certain conditions, the language strongly influences and determines the community, particularly affect the mindset, perception, and behavior. In contrast, in the case and other conditions, the community (mindset, perception, behavior, etc.) affect and determine the language. From this, the argument that the language reflects society and the culture of the society is reflected in language (Kartomihardjo, 1987: 229). Futhermore, Chaika (1982) states that language is a social mirror. Norms and values that existed in society embodied 
in the language through the choice of vocabulary, expressions, and so on (Kartomihardjo, 1990:17).

Every member of a c ommunity in using language always sh a re experiences, express social solidarity, planning, and deliberation. This suggests that language meant to present, express, and presents a world of experience, appreciation, reasoning, and so on. Therefore, language is never out of control, in fluence, or social relationship factors. Everything contained or prevailing in the society is always reflected and presented in the language (Kartomihardjo, 1990: 16), even control or influence the language.

Using society is a language society that upholds the Using language and culture. Every society that upholds the cultural values and social norms in using their language always have special expressions that describe the cultural val $u$ es and social norms of their society. Therefo $r e$, people who have a Using language and upholds Using culture als o have special expressions that describe the cult ural values and social $\mathrm{n}$ orms of Using society. Therefore, to understand the cultural values and social norms of Using society, the following ana 1 ysis present $\mathrm{s}$ a variety of traditional expressions in Using language that is used in everyday speech by the Using community. Through the study of the variety of expression, it is understood the meaning and function of such expressions used by Using community in everyday speech.

\section{THE VARIETIES OF TRADITIONAL EXPRESSION IN DAILY SPEECH OF USING COMMUNITY}

Based on the study of the daily speech of Using community, the traditional expression used by Using community can be classified into 6 categories. The expressions meant can be seen in the following description.

\section{The Parable Expression}

The parable is a maxim that a person uses or analogy by comparing the behavior of a situation or a person with a state of nature, objects, or beings of the universe (Basrie, 2013).There are two kinds of parable expression, ie the parable with explicitly marks and the parable without explicitly marks.
The parable expression with the explicitly marks is a metaphor explicit expression in the form of sentences likened (compared) with the actual state of the other conditions that exist in nature. In this expression, the speech of the parable explicitly marked with the words as, like, and so on. Using language in Banyuwangi traditional expressions, expressions imagery is characterized by the use of words and the feeling is like. Examples of the expression of the parable are as follows.

1) Koyo dene semur wader 'like wader fish stews'

2) Omonge ibarat idu geni 'His speaking as saliva of fire'

Expression (1) above is generally used to convey complaints related to his or her family life. The contents of the expressions describe the condition of a person's life miserable. The word stews of wader(is the name of fish) in Using language called koyong. From the word koyong, Using community generates word keloyongan, which means to 'life hard or not settled or nomadic to find enough income for life'. This expression is often used in conversation to discuss the topic of family life. The expressions is generally spoken by parents to describe the living conditions relating to the adequacy of fortune.

The expression (2) is an expression of praise or admiration. The wordsidu 'saliva' geni'fire' are metaphor expression. The words called an expression because they are a unit of language whose meaning is not the same as the combined meaning of its members. In other words, the expression is a construction whose meaning can not be inferred based on general rules. The expressions was used to liken the words of the wise. Something he said by this person often becomes a reality. In general, the expression of praise is not used in direct communication, but many used to tell the other person who was not involved in that conversation.

Different with the expressions above, in daily speech of Usingcommunity, the research findings also found parable expressions without explicitly marks. In these expressions, not characterized by words that express the parable because it has been spoken in the expression can be understood its meaning. The expression can be seen in the example (3) and (4) below. 
3) Angen-angene nggayuh lintang 'His dream to reach a star'

4) Dadi cangkem wong sak desa 'To be the talk of the entire village'

The expression (3) means the person who has high ideals, namely high as the stars in the sky. The expression can be used to express admiration for a person's desires. However, on the other hand, the expression can also be interpreted as a satire. If worn on the diligent, industrious, and strong-willed, this is an expression of admiration. However, if it is imposed on people who are lazy, this expression is a mockery. Meanwhile, the expression (4) are used to give a warning to someone. This expression describes how quickly a bad news was spread in the community. Therefore, the expressions also remind one to be careful in speaking and acting in society.

\section{The Proverb Expression}

Proverb is a group of words or sentences fixed structure and usually tells a particular purpose. Proverb included in the phrase, parables and thimbles. The proverb expression in daily speech of Using community is an expression that is a proverb in the form of a long speech declaring a state of Usingpeople. The proverb expression in Usinglanguage Used by Using community can be seen in the following examples.

5) Ancur koco, keroso-roso awak kulo

6) Geludhug jepretan, telek sing penyet 'Lighting strikes, stepping chicken droppings are helpless'

The expression (5) describes the condition of someone who is experiencing heartache. This expression is used someone who complained of feeling devastated condition for one thing. In the Using language, said ancur kocoit has the meaning of "roso", ie smooth substance that is coated on the glass making the glass can be used to look in the mirror. The sense of the word, formed keroso-roso expression which means to feel very miserable thought. Such expression is mostly used by young people who are exciting because of dating with boyfriend/girlfriend. In such times, the very dominant person's emotions, so everything is always felt and not thought out. Therefore, when there are problems and abandoned by her boyfriend, she felt heartache.
The expression (6) is used as a satire aimed at people who talk too much. Talkative person expressed by the maxim geledhek jepretan 'lightning flashing all over'. However, as discussed does not correspond to reality, the conditions expressed in the maxim telek sing penyet 'stepping on chicken manure alone helpless'. The expressions has meaning "people who only talk, but unable to carry out what was discussed. Therefore, the expressions is a mockery, also an adviceto someone so that is not excessive in talking.

\section{The Figurative Expression}

Figurative language is a deviation from what speakers of a language apprehends as the ordinary, or standard, significance or sequence of words, in order to achieve some special meaning or effect (Abrams, 1981:63).The figure of speech or a figure of speech referred to as a figure of rhetoric or rhetorical figure is a tool to expand the meaning of a word or group of words to obtain a certain effect by comparing or divide and associate the two things.Figurative expression is an expression that describes a condition or act of figuratively by using an object, behavior, or other description. To understand these expressions, one must know the word used as a reference these pengias. An example of this is the following quote allegoric expressions.

7) Manuk cemeng kuning dhadhane 'A black bird with a yellow chest'

8) Manuk cemeng putih dhadhane 'A black bird with a white chest'

Expression (7) is a figurative expression that describes the condition of a person who has to work hard to make ends meet. The black bird with yellow breast is a bird named 'srigunting'. From the word coined expressions bontang-banting awak kulo 'dangle my body', which means working hard to make ends meet. Therefore, the expression is used as a statement to complain or regret the fate of the less fortunate. This expression is rarely used by a person in a conversation involving the hearer but is more widely used to express a complaint himselves.

Expression (8) is an expression of the application or request for assistance from another person. The expressions spoke by someone who 
asks mercy of others. In the words, they used words manuk cemeng putih dhadhane 'bird black and white breast', the literal meaning of the name refers to the birds 'wulung'. From the word wulung was formed expression njaluk tulungwhose means 'to ask for help/mercy'. This expression is rarely used in conversation that the situation is serious, but it used to joke.

A variety of other figurative expression is an expression of everyday life. The expressions are composed of words or groups of words that are used in everyday communication, but the meaning of the words used to express the nature of the description or circumstances as are referred to by those words. This expression by its nature is similar to the expression in the form of proverbs. The expressions are as follows.

9) Bathang urip 'Living dead'

10) Cakem barong 'Big Mouth as the mouth of barong'

11) Jahe wono 'Ginger in the forest'

Expression (9) is an expression that serves to mock others or contracted for the actions of others. The word bathangmeans 'dead animal body'. Someone is said bathang urip 'carcass life' because the person does not have the feeling again like a dead animal. The expression in the use in daily communication refer to the nature and behavior of someone who does not care about the environment under any circumstances. Therefore, people use the expressions to express his annoyance. However, sometimes the expressions were used to tease her that behave according to the environmental conditions. In a joke between friends, such expressions are used to express distaste for the behavior of his less as expected. In jest, the person said with an expression that did not take it seriously.

The expression (10) is applied to people who like to expose the disgrace of others. In the expression, used the word cangkem'mouth' to analogize the activity of speaking, and barong 'wide-mouthed beast' the analogy of like going to prey on other animals. People figured with oral expression cakem barong'big mouth' is like talking about the evil of others. He always discloses the disgrace of others in place when there is any interlocutor. Therefore, the person who received the title of cangkem barong 'big mouth' is not appreciated by the public.

The expression (11) is used to describe the feelings and behavior of someone who is sad or agitated. It is usually expressed by and for young children or teenagers who are awaiting the arrival of a person who becomes her lover. This expression is often used by someone directly as strikes.

In addition to the examples above expression, the expression of everyday analogy can be exemplified in the following.

12) Balung nongko 'Jackfruit seeds'

13) Mbrengos lele 'Mustache catfish'

14) Ngudut cendhak 'Smoking short cigarette'

The expression (12) is often used by people who are in love. He always remembered and longed for someone to be her lover. In this case, the expression uses the words balung nongko'jackfruit seeds' in order to produce meaning katon riko'appearance you'or 'always remember you'. This expression is a statement that reflects a person's inner feelings or atmosphere.

Expression (13) describes a person's face is always sullen because she felt angry. It is used as a satire or warning, either delivered directly to the person concerned or indirectly. The use of this expression is intended for people who insinuated or reprimanded not feel hurt.

The expression (14) used to criticize the behavior of children who like to interrupt the conversation of others. Expressions like these are used directly by a parent to a child when the child is being interrupted her parents. Although it seems fiscal nature is also an expression of parental advice to his son.

\section{The "Pameo" Expressions}

Pameo is a proverb in the form of slogan. The slogan expressions is intended to encourage or liven the spoken. The examples of ecpression can be seen below.

15) Gedhang entek kelopo entek 'Banana exhausted coconut exhausted'

16) Wis tau gilik wis tau gepeng

The expression (15) describes a person's life is very poor. For Usingpeople, banana and coconut are the result of the earth which is a daily necessity. Therefore, if they do not have banana and coconut, they mean no longer have anything. This expression is generally only used as a statement, 
either revelation about the condition of himself and others. Meanwhile, the expression (16) describes the person who has had much experience in terms of employment. This expression is generally used by a speaker to recount the experiences that ever happened or tell other people who have had a lot of experience in a particular field.

\section{The Imagery Expressions}

The imagery is maxim that it aims for an explanation about everything likened to others. Tamsil used as advice, satirical, or warn to everything. The expression is an expression in the form of a parable in the form of allegory, rhyme, and rhythm. Example (17) and (18) The following is an example of the expression of imagery.

17) Gaur poleng, duwe dulur koyok celeng 'Gaur poleng, have a brother like wild boar'

18) Tenong-tenonga, irig mengkureb, ngomongngomonga, nglirik bain sing arep 'Tenongtenonga, irig down face. Moreover talking, just glancing unwilling'

Forms of speech in the expression (17) and (18) consists of two parts, namely (a) part sampiran (group of words without meaning, create sound effect only) and (b) part of the contents of expression (the meaning of the expression). Sampiran in those expressions is gaur poleng and tenong-tenonga, irig mengkureb. Sampiran speech does not give priority to the meaning, but the emphasis in the speech is the effect of rhyme and rhythm. The meaning of the expressions lies in the content of the expressions spoken in words duwe dulur koyok celeng'had a brother like boars' and ngomong-ngomonga, nglirik bain sing arep 'glance just do not want to, let alone say hello'.

The expression (17) is an expression that contains expletives indirect, or expressions that indicate the feeling angry. This expression is a rude revelation delivered by someone due to resentment against his actions. This expression is generally used by people to condemn or criticize his actions were inappropriate. Meanwhile, the expression (18) is an expression that shows the attitude of people who really do not like to others. This expression describes the hatred of one person to another. Therefore, if someone sees the proud and arrogant, he would say with this expressions.

\section{The Natural of Daily Expressions}

The expression in the form of straightforward expressions is an expression that in the form of a regular statement and are widely used in everyday conversation. That expression is interpreted based on the context of use. Examples of the expression are as follows.

19) Dowo jangkahe 'Stride length'

20) Dowo tangane 'Long hands'

The expression (19) is a compliment to someone who has the advantage in working, or people who are good at working. People who never give up on the difficulties encountered, and always striving to solve these difficulties, given the long title of the pace. If used in direct communication, this expression is widely used as an advisory partner liver function to boast he said.

People like to take the property of others said to be a dawa tangane or 'long hand'. The expression (20) is usually imposed on children, rarely used by adults, for adults who like to take other people's things directly say as 'theft' or 'thief'. Therefore, this expression is used as a reference to an ugly child who likes to take things that are not his.

\section{DISCUSSION: THE CULTURAL MEANING OF TRADITIONAL EXPRESSION}

Based on the description of the findings above, it can be said that the traditional expression of Using language used in daily speech by Using communities at Banyuwangi can be classified into (a) the parable expression, (b) the proverb expression, (c) the figurative expressions, (d) the "pameo" expressions, (e) the imagery expressions, and $(\mathrm{g})$ the natural on daily expression. Some varieties expressions spoken by Using community manifested in the form of sentences and groups of words. The study's findings are consistent with the statement Brunvand (Danandjaja, 1986) which explains that the expressions can be divided into four categories, namely (1) the truest expression, which has the properties (a) the complete sentence, (b) looks something changes, (c) a grain of truth or wisdom; (2) expression of incomplete sentences, which have the properties (a) the sentence is incomplete, (b) shape often changes, (c) rarely use discretion, and (d) is usually in the form of allegory; 
(3) expression of the parable, the expressions that usually begins with the words "like" or "as" and so on; and (4) an expression similar to the proverb, that is the expression used to insults, remarks, and answers short, sharp, and funny that is a warning.

The expressions in the speech of Using community Banyuwangi contain cultural values that are upheld and respected by Using society. Meaning contained in the expressions is understood and owned the by the Using community and serve as guidelines in carrying out cultural activities in daily life. Therefore, the traditional express ions in Using language as a means of expression the for the Using community who have a relationship with the characteristics of something expressed. Dilthey (in Kleden-Probonegoro, 2004) explains that the culture expression has characteristics (1) always has a specific meaning, (2) is a unique relationship with the expressed, (3) refers to the mental content of speakers; (4) arise in the context or as part of the configuration of the socio-cultural, (5) has a pattern or specific rules, and (6) has two properties are contradictory, that are purposively (may appear in the form of text, sound, and motion intentional) or nature coincidence (appearing as involuntary action, but still has meaning).

The varieties of traditional expressions used the in everyday speech of the Using community describe the community narrative style. In view of Harris and Moran (2005), the diversity of narrative style can be described as a picture of the diversity of the appearance of communicating that can be used as a vehicle to examine the cultural patterns of native speakers. Therefore, the diversity of the use of traditional expressions in speec $h$ of the Using communities is a picture of style and cultural diversity Using community in social life.

The Using community uses a variety of expressions in their speech to express a message, thoughts, feelings, or opinions to their speech participant. They use these expressions to convey praise, anger, aggravation, suggestions or advice, and pleasure. This means that the traditional speech that expresses serves as a means of expression for society or the community of native speakers in order to meet the social needs of the cultural and environmental demands. In the use of various forms of expression, they consider the participants, the topic, the situation, and the purpose. In line with this fact, Oke (1985:137) argues that the participant is expected able to select and apply a grain of manners in every act of speech acts. The component of the manners always takes into account the socio-cultural status of the participants, the relationship between participants, the place of speech, the situation of speech, the topic of speech, the atmosphere of speech, and the purpose of speech.

The arising of traditional expressions in everyday speech of the Using community can be viewed as a form of creativity in building a sociocultural media for their communications demands. As a social-culture media, the presence of expression in speech communication of Using community can be understood from two aspects, namely the internal and external aspects. On the internal side, the media culture emerged because of ideas or thoughts of a person or community because of concern for the needs of communication so compelled to develop their creativity in generating ideas. From the external aspect, culture media is created by individuals or communities to create models or certain forms in accordance with the needs of the community (Budianto, 2004).

In Using language, traditional expressions are used as a means ofcommunicating. This is mostly done by the people of Using because theUsing language is a language that does not have social stratification so tobuild politeness in social interaction, Using people applying other means inthe language. Likewise, to convince others, the expression is often used as apersuasion strategy in his speech. Altikriti (2016) explains that Persuadingsomeone means performing an act by using some form of communication,i.e., language. Language is an essential factor to politicians since politics isand even controlling their values. Traditional expression in this speech is addressed as a sign thatunderstanding the meaning require interpretation. The interpretation of themeaning of the language signs revealed in traditional expression for theUsing people is not difficult because the phrase is already consideredreasonable in their language. Johnston, van Roekel, Schembri (2015) explain that signed languages as a matter of fact that the languages of thelanguages and the phrases and the languages of the languages.

Based on the research findings above 
description, it can be argued that the traditional expressions used in Banyuwangi Using speech communities have a variety of functions. The use of the expressions is enabled for (a) criticism, (b) comments, (c) mock, (d) to convince, (e) states, (f) praise, (g) railed and cursed, (h) complained of, (i) warned and advised, and (j) begged and pleaded. Such functions are functions carried by the language spoken in the activities. This is in accordance with the opinion of Halliday (in Tarigan, 1986) who explains that the function of language in speaking of them is to follow chide, criticize, comment, reminder, stated, expect and so forth.

In line with the speech acts, Searle (1983: 22) points out five kinds of illocutionary acts, namely (1) representative acts, (2) commissive acts, (3) directive acts, (4) expressive acts, and (5) declarative acts. The representative act is a speech act that describes what and how an act as such, it requires persistence speakers on the truth of the proposition expressed, for example, speech acts of states, argue, and explain. The commissive act is a speech act that serves to encourage the speaker to do something, it requires speakers to plan how to act in the future, for example, promise, swear, and pray. The directive act is a speech act that encourages speech participant to do something. This requires speakers of trying to rule the hearer. The expressive act is a speech act concerning with attitudes and feelings. This requires speakers expressed psychological states, such as apologizing, thanking, praising, rejecting and blaming. Furthermore, the declarative act is a speech act that works establish or justify an act of another speech or earlier, for example, states of agree, disagree, and communicate (Levinson, 1983: 240).

Based on the findings, a traditional expression in Using language Banyuwangi no meaningful denotative; all connotative meaning, which includes associative meaning, affective meaning, and reflective meaning. The diversity meaning is very dependent on the relationship with the experience, history, goals, and feelings of the language concerned. In connection with this, Parera (1984) distinguishes meaning into two kinds, namely denotative and associative meanings.

\section{CONCLUSION}

A variety of traditional expressions in the speech of Using community is a reflection of the culture of Using community in speaking. The variety of the expressions used by the speaker to express a message, thoughts, feelings, or opinions to the partner he said. Various things conveyed through the expression are praise, anger, aggravation, suggestions or advice, and pleasure. Using language expressions meaning traditionally relies on partnerships with our diverse experiences, goals, and feelings of the language used.

The traditional expressions are nothing meaningful denotation, but all meaningful associative, which includes connotative meaning, affective meaning, and reflective meaning. In accordance with its meaning, a wide traditional expression in Banyuwangi Using speech community can be utilized for various communication functions. Using community utilizes the expressions to criticize, comment, ridicule, reassuring, stated, praising, reprimanding or blaming, complaining, reminding, advising, and asking.

\section{REFERENCES}

Abrams, M.H. (1981). A Glossary of Literary Terms. New York: Holt Rinehart and Winston.

Aksoro, Ach.(2004). Upacara Perkawinan Adat, dalam Majalah Budaya Jejak, nomor 06-2004.

Ali, H. (1991). Bahasa dan Sastra Using di Banyuwangi: A Report. Papers in the Java Language Congress at Semarang on June 30 - July 5 , 1991.

Altikriti, S. (2016). Persuasive Speech Acts in Barack Obama's Inaugural Speeches $(2009,2013)$ and The Last State of the Union Address (2016), retrieved fromInternational Journal of Linguistics,ISSN 1948-5425 2016, Vol. 8, No. 2

Ashraf, N. Bau, N., Nunn, N., and Voena, A. (2015). Bride Price and Female Education, retrieved from https://scholar.harvard.edu/nunn/publications/ bride-price-and-returns-education-women, downloaded May 2017

Auer, P. (2007). Style and Social Identities. Alternative Approaches to Linguistic Heterogeneity. Berlin: Mouton de Gruyter. 
Budianto, I.M. (2004). Media Budaya dan Ideologi. In Christomy, T. dan Yuwono, Untung (Eds.). Semiotika Budaya. Jakarta: Society and Culture Research Center, University of Indonesia.

Basrie, R. (2013).Pengertian Peribahasa, Ungkapan dan Perumpamaan, Retrieved on Descember, 2016 from http://reyismyname.blogspot co.id/2013/11/ pengertian-peribahasaungkapan-dan.html.

Chaika, E..(1982). Language: The Social Mirror. Rowley: Mass. Newbury House.

Danandjaja, J. (1982). Ungkapan Tradisional. Paper presented at the briefing and Upgrading writers of Culture, Directorate of Culture in Bogor.

Danandjaja, J. (1986). Folklor Indonesia: Ilmu Gosip, Dongeng, dan Lain-lain. Jakarta: Grafiti Pers.

Harris, P.R. dan Moran, R.T. (2005). Memahami Perbedaan-perbedaan Budaya in Deddy Mulyana dan Jalaluddin Rakhmat (Eds.). Komunikasi Antarbudaya: Panduan Komunikasi dengan orang-orang Berbeda Budaya.Bandung:PTRemajaRosdakarya.

Heinemann, J. Atallah, S. Rosenbaum, T. (2016). The Impact of Culture and Ethnicity on Sexuality and Sexual Function, in Curr Sex Health Rep (2016) 8:144-150, DOI 10.1007/s11930-0160088-8, doawnloaded May 2017

Johnston, T., van Roekel, J., and Schembri, A. (2015). On the Conventionalization of Mouth Actions in Australian Sign Language, retrieved fromLanguage and Speech 1-40, sagepub. co.uk/journalsPermissions.nav, DOI: 10.1177 /0023830915569334, las.sagepub.com

Kartomihardjo, S. (1987). Sosiolinguistik. Malang: IKIP Malang.

Kartomihardjo, S. (1990). Bentuk Bahasa Penolakan. Malang: Lembaga Penelitian.
Kementrian Kebudayaan dan Pariwisata. (2004). Kearifan Lokal di Lingkungan Masyarakat Using Banyuwangi Jawa Timur. Yogyakarta: Proyek Pemanfaatan Kebudayaan Daerah.

Kleden-Probonegoro, N. (2004). Ekspresi Karya (Seni) dan Politik Multikultural: Sebuah Pengantar, dalam Antropologi Indonesia 75, 2004 1, Retrieved on December 2015 from http:/www. jai.or.id/jurnal/2004/75/02ktp_nnk75.pdf,.

Levinson, S.C. (1983). Pragmatics. Cambridge: Cambridge University Press.

Marwoto. (1999). Kajian Hermeneutik Mantra Using Banyuwangi. Jember: Universitas Jember.

Nababan, P.W.J. (1984). Sosiolinguistik. Jakarta: PT Gramedia.

Oka, I G.N. (1985). Tata Krama Tutur Bahasa IndonesiainKumpulan Karangan Alumni IKIP Malang, 1975.

Parera, J.D. (1984). Belajar Mengemukakan Pendapat. Jakarta: Penerbit Erlangga.

Pusat Informasi Tentang Kesenian dan Kebudayaan. (2016).Pengertian Seni dan Budaya, retrieved on May 2016 from http://www.ragamseni. com/pengertian-budaya-menurut-para-ahlidilengkapi-dengan-unsur-unsurnya/.

Sastrowardojo, S. (1985). Sistem Budaya Jawa in Buchori Mochtar (ed.). Pandangan Budaya Daerah dan Pembinaan Masyarakat Pancasila. Jakarta: LIPI.

Searle, J.R. (1983). Speech Act. London: Cambridge University Press.

Suyitno, I. (2017). Traditional Expression in Social Interaction: The Cultural Prespective. Germany: Lambert Academic Publishing.

Tarigan, H.G. (1986). Pengajaran Pragmatik. Bandung: Angkasa. 